\title{
A premature but significant birth: The beginning of Korean Pavilion at the Venice Biennale and its aftermath
}

\section{M.Sc. Hyunah LEE}

Tutor: Prof. Dr. Andres Lepik; Department of Architecture, History of Architecture and Curatorial Practice, Technical University of Munich, Germany E-mail address: halee0113@naver.com

\begin{abstract}
Korean Pavilion is the last national pavilion at Giardini della Biennale in Venice, completed in 1995. This paper explores the unknown history of the pavilion that appeared in the 'year of art' of South Korea and the centennial anniversary of the Venice Biennale under the legitimated idealistic name of "Korean" Pavilion. It investigates the politics of the pavilion's beginning and argues its significance as a premature, but earliest platform of Korean architecture. Also, it observes developing discourse on architecture exhibition and its archive in contemporary Korean architecture reflected in the Korean Pavilion in the last decade. As a result, this paper discusses the pavilion's ironic contrast, oscillating between its start made in the politics of the national pavilion at the Venice Biennale, and its transformation into being the oldest and most representative architectural platform for Korean architecture.
\end{abstract}

KEYWORDS: architecture exhibition; Korean Pavilion; Venice Biennale 


\section{A premature but significant birth: The beginning of Korean Pavilion at the Venice Biennale and its aftermath}

Countries having a pavilion at Giardini della Biennale in Venice highlights two aspects of their nation concerning architecture. One is the pavilion building itself, made in the past but permanent, through which the artistic and architectural image of the country is represented. A pavilion, which is supposed to be temporary architecture (as the word derived from a butterfly), however, lives perennially in this particular context of the Venice Biennale (Mossessian 2013). The other is an architecture exhibition displayed inside the building, which is about contemporary architecture on the actual projects of the time biannually, thus being ephemeral. At the Venice Biennale, the architecture of pavilion and architecture in pavilion have inextricable relations in this paradox.

However, despite this close connection, the birth of pavilion architecture in Venice hardly embarked on the desire for architectural presentation nor sheerly for art, but for the politics of national representation as is the case with the Korean Pavilion. The idea of building national pavilions originated from the internationality that the biennale aimed for (Martini 2013), hence ironically required worldwide-local participation that entails the selection of nations in the restricted geographical situation of the Giardini (Moreno 2010). Among the thirty pavilions at the Giardini, the Korean Pavilion not only marks the endpoint of the 20th century's national pavilion at the Giardini, which started with Belgium's in 1907, but also attests to the politics in this choice of architecture.

The Korean Pavilion, designed by South Korean architect Seok Chul Kim and Venetian architect Franco Mancuso, was completed in 1995 between the Japanese and German pavilions. Though rejected many times, South Korea applied for a new pavilion candidate from its first participation of South Korean artists in 1986, when it became the government's official project under the department of the South Korean Ministry of Culture (Nam 1995). The crucial moment that propelled the realization of the architecture was on the occasion art biennale, when Korean-born video artist Nam June Paik won the Golden Lion Award at the German Pavilion (Kim 1993b). In contrast to the award-winning at another country's entry, the poor exhibit of South Korean artists at the corner space of the Italian Pavilion's underground was regarded as disgraceful and pitiable (Kim 1993a), the project came to the fore again with the government's more enthusiastic drive. 
"It is unfortunate ... a the Venice Biennial only the Japanese Pavilion represents Asia. As one of the major Asian countries, Korea should also be represented. This would support the theme of the 100th Venice Biennial 'Balancing the Culture of East, West, South, and North'." (Lee 1993) In a letter sent to the then Mayor of Venice, Giovanni Troiani, from South Korean Minister of Culture Min Sup Lee in November 1993, the proposal's legitimacy stands for the geopolitical cause, in conjunction with the timely appropriateness for the centennial anniversary of the biennale coming up in 1995. Additionally, the ministry's declaration in the same year that there was to be a 'year of art' made the Korean pavilion project an internal goal as well as the external legitimation. Under such circumstances, the maneuver of reusing the existing brick building at the current site planned by the architects (Cho and Pai 2014) consequently led to the formal grant for the pavilion construction in 1994.

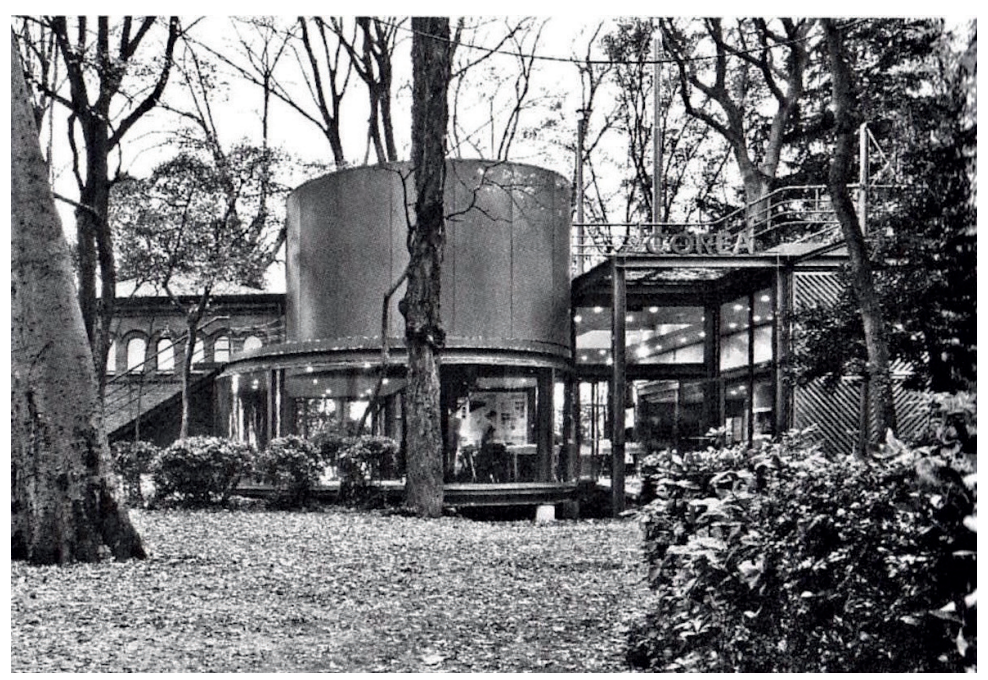

Fig.1. The Korean Pavilion (Mulazzani 2014)

The distinctive feature of the Korean Pavilion also lies in its unusual name, which is rarely noticeable to audiences at first sight. It houses the Republic of Korea (South Korea) continuously, whereas the sign of the pavilion 'Corea (Korea)' implies both South and North Korea. Unlike other few examples, such as the Czech and Slovak Republics using a joint pavilion and the Serbian Pavilion using a Yugoslavian name, the Korean Pavilion does not reflect the existing past that has changed through the time. Conversely, it reflects a realistic but fictitious scenario of the two Korea's reunification, proposed by the artist Paik (Lee 2015; Lee 2013). Here, Korea's geopolitical situation, as not only an Asian country, but also as one of the divided countries in the 
world, was decisively considered in the architectural process for the peaceful gesture of the biennale despite the uncertainty of the future.

Notwithstanding the politics surrounding its birth, the erection of the Korean Pavilion enabled South Korean architecture to have a presence in Venice, which later brought with it significant momentum in Korean architecture and its exhibition history. In 2014, the retrospective angle on the Korean Pavilion's beginning (of using the space for both Koreas) was materialized by South Korea for the first time within the theme of showing two different types of modernity and gave the first Golden Lion Award. Together, by the 2010s, there was an exponential increase in architecture exhibitions in South Korea. In the background of joining in an international trend of consuming culture by exhibitions, South Korean architecture belatedly entered into a time of exhibition culture (Pai 2015) with the apical achievement at the Korean Pavilion as its genesis.

The internal and external development of the architecture exhibition of South Korea met in Venice in 2014. However, the initial relation between the architecture, and the architecture exhibited in the building was different. The construction of the Korean Pavilion allowed for a fortuitous opportunity to stage South Korean architecture from 1996 at the 6th Venice Architecture Biennale. Yet, it was still a premature platform at the beginning. The first participation of architecture at the place had gravity as an inauguration, while the exhibition demonstrated a lack of experience in preparation and display (Kim 1996). The exhibition highlighted two major international competition projects from South Korea without a cohesive theme and a title that was regarded as an equal cultural presence of Asian architecture in the west (Kang 1996), thus remaining within the extent of the geopolitical perspective inherited from the pavilion architecture's outset.

Given these points, the contrast between the triggers and results of the exhibitions in 1996 and 2014 illustrates the full circle of the Korean Pavilion architecture and architectural contents and reveals dynamic changes in-between. More precisely, it was not a mere transition from passive attitude to active engagement but was in parallel with growing discourses, specifically regarding architecture museums and architectural archives, which intimately related to architecture exhibition. Domestically, the urgency of having architectural archiving institutions conferred from the mid-2000s was recently realized with independent architecture museums and departments. With the appearance of the first architecture curator at the National Museum of Modern and Contemporary Art (MMCA) in South Korea, architecture exhibition headed by archival research that Korean architecture lacked, has become more wide-spread. 
At the Venice Architecture Biennale in 2018, the Korean Pavilion presented an exhibition that consists of two archives: 'Absent Archive'; and 'Emergent Archive'. Here, the critical perspective toward the past and the present in the format of architecture on display merged in archival records and turned into architectural work as they were. It signifies the pavilion's current role and importance, transformed within the Korean architecture scene and the Biennale's perennial nature. Indeed, the trajectory of the Korean Pavilion resulting from its political birth bears its premature start and the evolution of domestic discussion on architecture and architecture exhibition in South Korea at the same time. In this context, the beginning of the Korean Pavilion, initiated from peripheral ambitions, brought Korean architecture an accidental yet significant opportunity for having its first standing architectural platform as the aftermath.

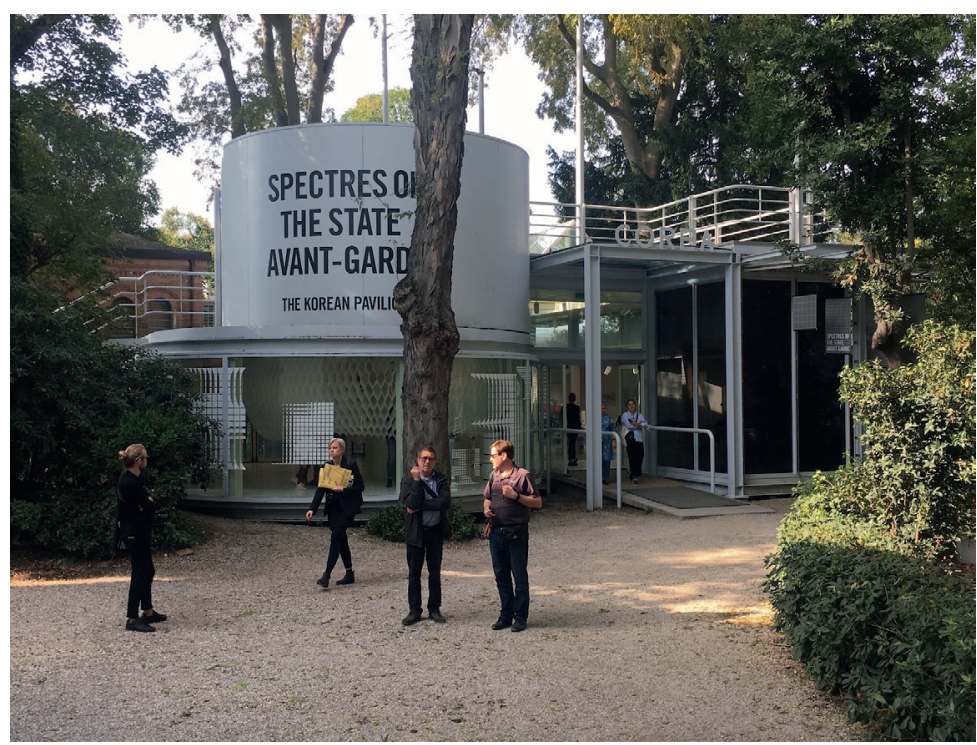

Fig.2. The Korean Pavilion in 2018 (Author) 


\section{References}

HO, M. AND H. PAI Crow's Eye View: The Korean Peninsula. Edtion ed.: Archilife, 2014. ISBN 8996450863.

KANG, S.-W. Designing the Future with Respect for What Exists. In Di Mostra Internazionale di Architettura Venezia 1996. 1996.

KIM, H. Visiting the '93 Venice Biennale, Interview with Nam June Paik. Monthly Art, 1993a, 5.

KIM, H.-J. Decision of participating works in 96 Venice Biennale Architectural Exhibition. SPACE, 1996, 347, 22-23.

KIM, S. Status and Plan of the Project of Korean Pavilion at the Venice Biennale. Republic of korea: 1993b.

LEE, M.-S. In J. TROIANI. Seoul, Republic of Korea, 1993.

LEE, S. Virtual Space and National Division: Crow's Eye View: The Korean Peninsula at the Venice Architecture Biennale (2014). Journal of Korean Studies, 2015, 20(2), 291-332.

LEE, Y. Invention of visionary language - The heros of the Korean Pavilion at the Venice Biennale. In Kimsooja to Breath: Bottari. 2013.

MARTINI, F. Pavilions / Architecture at the Venice Biennale. In., 2013.

MORENO, V. Venice Biennale and the Canada Pavilion: Politics of representation in the Gardens of Art. University of Toronto Faculty of Information Quarterly, 2010, 3(1).

MOSSESSIAN, M. Being as Building, the Korean Papillione. In Kimsooja. To Breathe: Bottari. 2013.

MULAZZANI, M. Guide to the Pavilions of the Venice Biennale since 1887. Edtion ed.: Electa, 2014. ISBN 8891800511.

NAM, I.-K. Korean Pavilion Opens at the Venice Biennale: The Proud Site Where East and West Meet -Report on the Process of the Korean Pavilion's Construction. Korean Culture and Art Journal, 1995, 197.

PAI, H. Sensation and consideration in the Time of Exhibition. Architecture News, 2015, 15. 